\title{
Comparing three induction chemotherapy regimens for patients with locoregionally advanced nasopharyngeal carcinoma based on TNM stage and plasma Epstein-Barr virus DNA level
}

Sai-Lan Liu ${ }^{1,2+}$, Xue-Song Sun ${ }^{1,2+}$, Hao-Jun Xie ${ }^{1,2+}$, Qiu-Yan Chen ${ }^{1,2}$, Huan-Xin Lin ${ }^{1,3}$, Hu Liang ${ }^{1,2}$, Yu-Jing Liang ${ }^{1,2}$, Xiao-Yun Li ${ }^{1,2}$, Jin-Jie Yan ${ }^{1,2}$, Chao Lin ${ }^{1,2}$, Zhen-Chong Yang ${ }^{1,2}$, Shan-Shan Guo ${ }^{1,2}$, Li-Ting Liu 1,2, Qing-Nan Tang ${ }^{1,2}$, Yu-Yun Du ${ }^{1,2}$, Lin-Quan Tang ${ }^{1,2^{*}+}$, Ling Guo ${ }^{1,2^{*}+}$ and Hai-Qiang Mai ${ }^{1,2^{*}}$

\begin{abstract}
Background: We compared the efficacy and toxicity of three IC regimens (TPF: taxanes, cisplatin, and 5-fluorouracil; TP: taxanes and cisplatin; and PF: cisplatin and 5-fluorouracil) followed by CCRT in locoregionally advanced NPC.

Methods: The retrospective study involved 1354 patients with newly diagnosed stage III-IVA NPC treated with IC and CCRT. The median follow-up time in our cohort was 50 months. Based on EBV DNA level, all the patients with stage IV were divided into low- (pre-EBV DNA < 1500 copies) and high-risk group (pre-EBV DNA $\geq 1500$ copies). Progression free survival (PFS), overall survival (OS), locoregional relapse free survival (LRFS), distant metastasis free survival (DMFS) and grade 3-4 toxicities were compared among different IC regimens. The survival rates were compared using log-rank test and a Cox proportional hazards model was used to perform multivariate analyses.

Results: A multivariate analysis revealed TPF to be more effective than TP. Among stage III patients, no significant difference in clinical outcome between the different IC regimens was showed, while TPF was associated with significantly better survival conditions in the stage IV patients. A further subgroup analysis revealed that only patients with pre-EBV DNA $\geq 1500$ copies could benefit from the application of TPF among stage IV NPC. In terms of acute toxicities, PF was associated with fewer grade 3/4 acute toxicities.

Conclusions: In low-risk NPC patients, PF-based IC showed similar efficacy as TPF and TP but was associated with fewer grade 3/4 acute toxicities. In high-risk patients, however, the TPF regimen was superior to PF and TP, although grade $3 / 4$ toxicities were more common with the TPF regimen.
\end{abstract}

Keywords: Nasopharyngeal carcinoma, Induction chemotherapy, Prognosis, Plasma Epstein-Barr virus

\footnotetext{
* Correspondence: tanglq@sysucc.org.cn; guoling@sysucc.org.cn; maihq@sysucc.org.cn

†Sai-Lan Liu, Xue-Song Sun and Hao-Jun Xie are contributed equally

${ }^{+}$Lin-Quan Tang, Ling Guo and Hai-Qiang Mai the senior authors contributed

equally to this work.

${ }^{1}$ Collaborative Innovation Center for Cancer Medicine, Guangdong Key Laboratory of Nasopharyngeal Carcinoma Diagnosis and Therapy, Sun Yat-sen University Cancer Center; State Key Laboratory of Oncology in South China, 651 Dongfeng Road East, Guangzhou 510060, People's Republic of China

Full list of author information is available at the end of the article
}

(c) The Author(s). 2020 Open Access This article is distributed under the terms of the Creative Commons Attribution 4.0 International License (http://creativecommons.org/licenses/by/4.0/), which permits unrestricted use, distribution, and reproduction in any medium, provided you give appropriate credit to the original author(s) and the source, provide a link to the Creative Commons license, and indicate if changes were made. The Creative Commons Public Domain Dedication waiver (http://creativecommons.org/publicdomain/zero/1.0/) applies to the data made available in this article, unless otherwise stated. 


\section{Background}

Nasopharyngeal carcinoma (NPC) is a malignant disease arising from the nasopharyngeal epithelium. It is most endemic to Southern China, where $50-80$ cases per 100,000 persons are reported each year [1]. Because of the radiosensitive nature of NPC and the typically deep-seated location of the lesions, radiation therapy (RT) is the primary treatment for NPC [2]. The development of modern RT has resulted in improved local control rates for NPC [3-5]. However, the prevention of distant metastasis in advanced NPC remains unsatisfactory and is the main cause of treatment failure [6]. Therefore, an effective treatment protocol is necessary to achieve better outcomes in these cases.

For non-metastatic locoregionally advanced NPC, concurrent chemoradiation therapy (CCRT) has been shown to be more effective than RT alone and has been accepted as the standard treatment for advanced NPC [7, 8]. Nevertheless, induction chemotherapy (IC) combined with the established CCRT regimen has recently attracted attention for the management of advanced NPC. The use of IC followed by definitive CCRT is associated with decreased distant metastases, which could improve clinical outcomes [9-15].

IC has been widely used in clinical practice; however, thus far, there is no consensus on the most suitable IC regimen. Therefore, it is important to evaluate the different IC regimens according to their efficacy and toxicity. Unfortunately, there was no large-scale clinical trial with convincing results to compare the efficacy of different IC regimen up to now [16]. To address this problem, in this study, we retrospectively analyzed 1354 NPC patients who received IC before concurrent chemotherapy. Taxanes, cisplatin, and 5-fluorouracil (TPF); cisplatin and 5fluorouracil (PF); and taxanes and cisplatin (TP) were the most frequently used IC regimens in our center and were evaluated in this cohort. We especially analyzed the differences in patients' survival outcomes in the three IC groups as well as the acute toxicity of the regimens. Besides, the plasma EBV DNA level has been proved to be useful in the prognostic prediction for NPC [17]. Accordingly, we divided patients in different risk level based on their pretreatment EBV DNA and compared the curative effect of these three IC regimens in different subgroups, which was not reported in previous studies.

\section{Methods}

\section{Patients}

From 2008 to 2017, 1354 previously untreated NPC patients were enrolled in the study. The eligibility criteria for inclusion were newly diagnosed biopsy-proven NPC; receipt of first-line $\mathrm{IC}$ for at least 2 cycles followed by CCRT; Karnofsky performance score (KPS) > 70; adequate organ functions and with available hematological sample and EBV serology results. Key exclusion criteria were as the following: received palliative treatment; a history of malignancy; received previous anti-tumor treatment (radiotherapy, chemotherapy, or surgery [except diagnostic procedures]); the presence of lactation, pregnancy or severe coexisting illness.

The following examinations were performed for all patients: a complete physical examination, head and neck magnetic resonance imaging (MRI), chest radiography, abdominal sonography, electrocardiography, bone scan, nasopharyngoscopy, and complete blood count including differential cell counts, biochemical profile, and EBV serology. For partial patients, positron emission tomography/computed tomography (PET-CT) was also optionally performed to evaluate distant lesions. The study was approved by the Sun Yat-sen University Cancer Center Research Ethics Committee.

\section{Chemotherapy and RT}

All patients received one of the following IC regimens: PF (comprising cisplatin $\left[80-100 \mathrm{mg} / \mathrm{m}^{2}\right.$, day 1] and 5fluorouracil $\left[800-1000 \mathrm{mg} / \mathrm{m}^{2}\right.$, day $1-5,120 \mathrm{~h}$ of continuous intravenous infusion]); TP (comprising docetaxel [75 $\mathrm{mg} / \mathrm{m}^{2}$, day 1$]$, paclitaxel $\left[150-180 \mathrm{mg} / \mathrm{m}^{2}\right.$, day 1] or paclitaxel liposome [150-180 $\mathrm{mg} / \mathrm{m}^{2}$, day 1], and cisplatin [20$25 \mathrm{mg} / \mathrm{m}^{2} /$ day, day 1-3]); and TPF (comprising docetaxel [60 $\mathrm{mg} / \mathrm{m}^{2}$, day 1$]$, paclitaxel $\left[135 \mathrm{mg} / \mathrm{m}^{2}\right.$, day 1] or paclitaxel liposome $\left[135 \mathrm{mg} / \mathrm{m}^{2}\right.$, day 1$]$, cisplatin $[20-25 \mathrm{mg} /$ $\mathrm{m}^{2} /$ day, days 1-3], and 5-fluorouracil [500-800 $\mathrm{mg} / \mathrm{m}^{2}$, $120 \mathrm{~h}$ of continuous intravenous infusion]). All regimens were administered every 3 weeks over $2-4$ cycles. RT was administered to the nasopharynx and neck by using intensity-modulated RT (IMRT) or two-dimensional RT (2D-CRT). IC was followed by concurrent cisplatin-based chemotherapy $\left(80-100 \mathrm{mg} / \mathrm{m}^{2}\right.$ every 3 weeks or $30-40$ $\mathrm{mg} / \mathrm{m}^{2}$ weekly) $[7,18]$. Five daily fractions of a total dose of $68 \sim 70$ Gy at about 2 Gy per fraction were prescribed per week. Other details of the IMRT plan were in line with the principles described in previous studies [19-21].

\section{Outcome and follow-up}

The primary endpoint of our study was PFS, defined as the period from the first day of treatment to the date of disease progression or death from any cause. The other clinical endpoints were OS (defined as the period from the date of treatment to the date of death from any cause), LRFS (defined as the period from date of treatment to the date of local/regional relapse), and distant metastasis-free survival (DMFS), (defined as the time from date of treatment to the date of distant metastasis). Hematological reactions were evaluated for acute ICassociated toxicity, classified based on the National Cancer Institute Common Terminology Criteria for Adverse Events version 4.0, and compared between the groups. Physical examination, nasopharyngoscopy, and 
MRI of the head and neck were performed 3-6 months after RT completion. We evaluated tumor responses according to the Response Evaluation Criteria in Solid Tumors [22]. After treatment completion, the patients were evaluated every 3 months during the first 3 years and every 6 months thereafter until death. Nasopharyngoscopy, head and neck MRI, chest radiography, abdominal sonography, and plasma EBV DNA measurement were routinely performed.

\section{Statistical analysis}

Statistical analyses were performed using SPSS package for Windows version 22.0 (Chicago, IL). Correlations between the different IC regimens and clinical characteristics

Table 1 Patient demographics and clinical characteristics

\begin{tabular}{|c|c|c|c|c|c|}
\hline & & $\operatorname{TPF}(n=772)$ & $\operatorname{PF}(n=340)$ & $\mathrm{TP}(n=242)$ & \\
\hline Characteristics & No. (\%) & No. (\%) & No. (\%) & No. (\%) & $P$ value \\
\hline Age, years & & & & & $0.307^{a}$ \\
\hline Median (range) & $44(8-74)$ & $43(8-74)$ & $44(15-71)$ & $46(18-71)$ & \\
\hline$<45$ & 698(51.6) & $411(53.2)$ & $171(50.3)$ & 116(47.9) & \\
\hline$\geq 45$ & $656(48.4)$ & $361(46.8)$ & 169(49.7) & $126(52.1)$ & \\
\hline Sex & & & & & $0.580^{\mathrm{a}}$ \\
\hline Female & $335(24.7)$ & 184(23.8) & $91(26.8)$ & $60(24.8)$ & \\
\hline Male & 1019(75.3) & $588(76.2)$ & 249(73.2) & 182(75.2) & \\
\hline Pathological type & & & & & $0.217^{b}$ \\
\hline WHO type I & $4(0.3)$ & $3(0.4)$ & $1(0.3)$ & $0(0.0)$ & \\
\hline WHO type II & $9(0.7)$ & $4(0.5)$ & $5(1.5)$ & $0(0.0)$ & \\
\hline WHO type III & $1341(99.0)$ & 765(99.1) & $334(98.2)$ & $242(100)$ & \\
\hline T stage $^{c}$ & & & & & $0.199^{a}$ \\
\hline T1 & $18(1.3)$ & $11(1.4)$ & $5(1.5)$ & $2(0.8)$ & \\
\hline $\mathrm{T} 2$ & 149(11.0) & $71(9.2)$ & $49(14.4)$ & $29(12.0)$ & \\
\hline T3 & $665(49.1)$ & $379(49.1)$ & 168(49.4) & $118(48.8)$ & \\
\hline T4 & $522(38.6)$ & $311(40.3)$ & $118(34.7)$ & $93(38.4)$ & \\
\hline N stage ${ }^{c}$ & & & & & $<0.001^{a}$ \\
\hline No & $35(2.6)$ & $15(1.9)$ & $11(3.2)$ & $9(3.7)$ & \\
\hline N1 & $315(23.3)$ & 193(25.0) & $57(16.8)$ & $65(26.9)$ & \\
\hline N2 & $695(51.3)$ & $367(47.5)$ & 197(57.9) & $131(54.1)$ & \\
\hline N3 & $309(22.8)$ & 197(25.5) & $75(22.1)$ & $37(15.3)$ & \\
\hline Clinical stage $e^{c}$ & & & & & $0.005^{\mathrm{a}}$ \\
\hline III & $612(45.2)$ & $320(41.5)$ & $167(49.1)$ & $125(51.7)$ & \\
\hline IVa-b & $742(54.8)$ & $452(58.5)$ & 173(50.9) & 117(48.3) & \\
\hline EBV DNA & & & & & $<0.001^{a}$ \\
\hline$\geq 1500$ & $875(64.6)$ & $514(66.6)$ & $231(67.9)$ & 130(53.7) & \\
\hline$<1500$ & 479(35.4) & $258(33.4)$ & 109(32.1) & $112(46.3)$ & \\
\hline RT technique & & & & & $<0.001^{a}$ \\
\hline 2D RT & 119(8.8) & $7(0.9)$ & 101(29.7) & $11(4.5)$ & \\
\hline IMRT & 1235(91.2) & $765(99.1)$ & 239(70.3) & $231(95.5)$ & \\
\hline $\mathrm{CCD}\left(\mathrm{mg} / \mathrm{m}^{2}\right)$ & & & & & $0.127^{\mathrm{a}}$ \\
\hline Median (range) & $160(20-300)$ & $160(25-300)$ & $160(40-250)$ & $160(20-300)$ & \\
\hline$\geq 200$ & 295(21.8) & 183(23.7) & $63(18.5)$ & $49(20.2)$ & \\
\hline$<200$ & 1059(78.2) & $589(76.3)$ & $277(81.5)$ & 193(79.8) & \\
\hline
\end{tabular}

Abbreviations: TPF Taxanes plus cisplatin with fluorouracil, PF Cisplatin with fluorouracil, TP Taxanes with cisplatin, EBV Epstein-Barr virus, CCD Cumulative cisplatin dose during radiotherapy

${ }^{a} P$ values were calculated by the Chi-square test. ${ }^{b} P$ value calculated with Fisher's exact test

'According to the 7th edition of UICC/AJCC staging system 
Table 2 Overall response rates at central review after the induction phase

\begin{tabular}{lllll}
\hline & $\operatorname{TPF}(n=707)$ & $\mathrm{PF}(n=137)$ & $\mathrm{TP}(n=147)$ & $P$ value \\
\hline Complete response & $14(2.0 \%)$ & $3(2.2 \%)$ & $3(2.0 \%)$ & 0.013 \\
Partial response & $548(77.5 \%)$ & $89(65.0 \%)$ & $102(69.4 \%)$ & \\
Stable disease & $142(20.1 \%)$ & $45(32.8 \%)$ & $40(27.2 \%)$ & \\
Progressive disease & $3(0.4 \%)$ & $0(0.0 \%)$ & $2(1.4 \%)$ & \\
\hline
\end{tabular}

$P$ value calculated with Fisher's exact test

Abbreviations: TPF Taxanes plus cisplatin with fluorouracil, PF Cisplatin with

fluorouracil, TP Taxanes with cisplatin

of NPC were evaluated using the $x^{2}$ or Fisher's exact test as appropriate. Kaplan-Meier survival curves were used to evaluate long-term survival; the survival rates were compared using log-rank test. A Cox proportional hazards model was used to perform multivariate analyses involving the following variables: age, sex, $\mathrm{T}$ stage, $\mathrm{N}$ stage, clinical stage, EBV DNA, and IC regimen. All analyses were twosided. The level of significance was set at $P<0.05$.

\section{Results}

\section{Patient characteristics}

New, consecutive patients (1354 patients including 335 [24.7\%] females and 1019 [75.3\%] males) diagnosed with non-metastatic NPC between June 2008 and November 2017 were included in this study. In the cohort, $1341(99.0 \%)$ patients had WHO type III disease. The median patient age was $44(8-74)$ years, and 772 (57.0\%), 340 (25.1\%), and 242 (17.9\%) patients received TPF, PF, and TP chemotherapy, respectively. The median follow-up time was 27.3 months (range: 0.5-113.2 months) in the whole cohort, and 25.1 months (range: 3.1-90.8 months), 42.6 months (range: 3.2-113.2 months) and 25.7 months (range: $0.5-87.8$ months) in TPF, PF and TP groups respectively. The cumulative cisplatin dose $(\mathrm{CCD})$ was less than $200 \mathrm{mg} / \mathrm{m}^{2}$ in most patients $(1059 / 1354$, 78.2\%). The patients' other baseline characteristics are shown in Table 1.
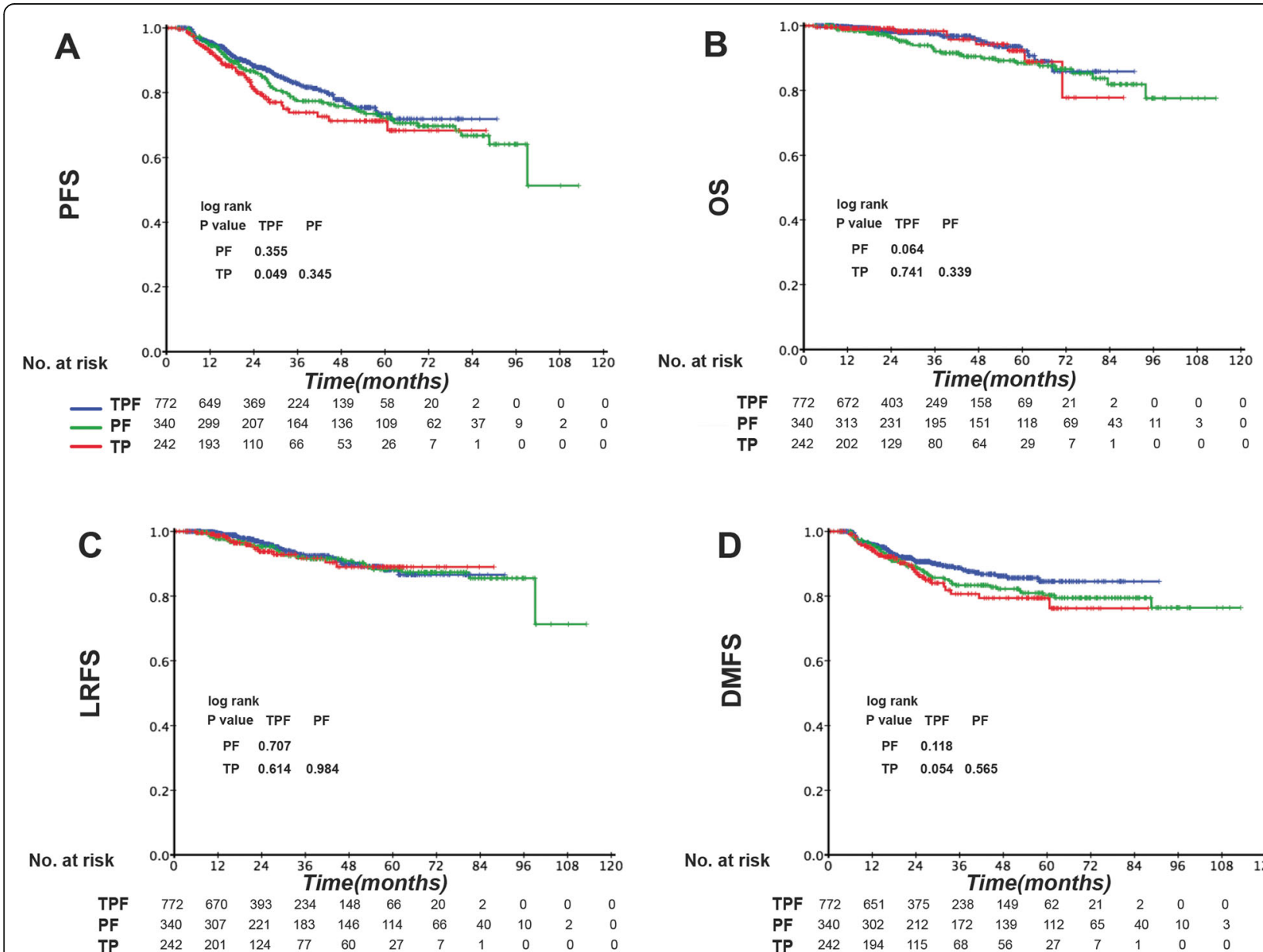

Fig. 1 Kaplan-Meier (a) progression-free survival (PFS), b overall survival (OS), c locoregional relapse-free survival (LRFS), and $\mathbf{d}$ distant metastasisfree survival (DMFS) curves for the 1384 stage III-IVb NPC patients receiving induction TPF, PF, or TP 


\section{Survival analysis of patients treated with different IC regimens}

The 3-year PFS, OS, LRFS, and DMFS rates for the entire patient cohort were 79.4, 95.9, 88.0, and 85.6\%, respectively. Regarding short-term tumor response, the complete response (CR)/partial response (PR) ratio was higher (79.7\%) in TPF-receiving patients than in PF- and TP-receiving patients (67.2 and 71.4\%, respectively; $P<0.001$, Table 2 ). However, differences in long-term survival were only observed between TPF- and TP-treated patients and not between TPF- and PF-treated patients. Furthermore, the corresponding 3-year PFS, OS, LRFS and DMFS rates for TPF vs. PF vs. TP were $82.4 \%$ vs. $77.4 \%$ vs. $73.8 \%$ ( $\mathrm{P}_{\text {TPF vs. }}$ $\mathrm{PF}=0.335, \mathrm{P}_{\mathrm{TPF}}$ vs. TP $=0.049, \mathrm{P}_{\mathrm{PF}}$ vs. $\mathrm{TP}=0.345 ;$ Fig. 1a), 97.2\% vs. $92.1 \%$ vs. $97.0 \%\left(\mathrm{P}_{\mathrm{TPF}}\right.$ vs. $\mathrm{PF}=0.064, \mathrm{P}_{\mathrm{TPF}}$ vs. $\mathrm{TP}=$ 0.741, $\mathrm{P}_{\mathrm{PF} \text { vs. тP }}=0.339$; Fig. $\left.1 \mathrm{~b}\right), 92.5 \%$ vs. $91.5 \%$ vs. $91.7 \%$ $\left(\mathrm{P}_{\mathrm{TPF} \text { vs. } \mathrm{PF}}=0.707, \mathrm{P}_{\mathrm{TPF} \text { vs. TP }}=0.614, \mathrm{P}_{\mathrm{PF} \text { vs. } \mathrm{TP}}=0.984\right.$; Fig. 1c), and $88.4 \%$ vs. $83.3 \%$ vs. $80.7 \%\left(\mathrm{P}_{\mathrm{TPF}}\right.$ vs. $\mathrm{PF}=0.118, \mathrm{P}_{\mathrm{TPF}}$ vs. TP $=0.054, \mathrm{P}_{\mathrm{PF} \text { vs. TP }}=0.565$; Fig. $1 \mathrm{~d}$ ) (Table 6 in Appendix 1 ). In the multivariate analysis, the following prognostic factors were evaluated: age, gender, pathological type, $\mathrm{T}$ stage, N stage, EBV DNA, and IC regimen. As shown in Table 3, TPF was associated with significantly better OS and DMFS than TP (OS: HR, 1.630; 95\% CI, 0.151-2.308; $P=0.006$; DMFS: HR, 1. 692; 95\% CI, 1.115-2.569; $P=0.013$ ), whereas not an independent prognostic factor compared with PF in all clinical outcome. As there was higher proportion of 2DRT in PF group, we performed multivariate analysis involving RT method in PF group. As shown in the supplementary table, RT method was not an independent prognostic factor for all endpoints, indicating that its impact on survival conditions was relatively small (Table 7 in Appendix 2).

Subgroup analysis according to the TNM stage and EBV level Patients at different TNM stages exhibited different tumor burdens and treatment failure rates. Thus, we divided the patients according to the TNM stage into stage III and IV disease groups (Table 8 in Appendix 3) and compared the prognostic impact of the IC regimens in the two groups. Among the three IC regimens, patients in TPF groups showed the highest complete response/ partial response rate after the induction phase (TPF vs. PF vs. TP: $79.5 \%$ vs. $67.2 \%$ vs. $71.4 \%, P=0.013)$. Stage III patients showed no significant difference in clinical outcome between the different IC regimens (Fig. 2). However, in the IVA-IVB stage subgroup, TPF was associated with significantly better OS and DMFS than was PF and better PFS and DMFS than was TP (Fig. 3). EBV DNA is a prognostic factor for NPC patients. Therefore, we divided stage IV patients into lowrisk and high-risk subgroups according to the EBV DNA level. Interestingly, prognostic factors differed between these two subgroups. Among low-risk patients (pre-EBV DNA $<1500$ copies), the 3-year PFS, OS, LRFS, and DMFS rates in the different IC groups were similar and the
Table 3 Multivariable analysis of prognostic factors for III-IVb NPC patients

\begin{tabular}{|c|c|c|}
\hline & Hazard ratio* $(95 \% \mathrm{Cl})$ & $P$ value \\
\hline \multicolumn{3}{|l|}{ Progression-free survival } \\
\hline Age (y) ( $\geq 45$ vs. $<45)$ & $1.543(1.100-2.164)$ & 0.012 \\
\hline Gender(F vs. M) & 1.055(0.814-1.366) & 0.686 \\
\hline T category (3-4 vs. 1-2) & $1.280(0.846-1.937)$ & 0.242 \\
\hline N category (2-3 vs. $0-1)$ & $1.357(0.977-1.886)$ & 0.069 \\
\hline Overall stage (IVa-b vs. III) & 1.487(1.133-1.951) & 0.004 \\
\hline EBV DNA & $1.579(1.151-2.164)$ & 0.005 \\
\hline IC regimen; PF vs. TPF & 1.189(0.880-1.605) & 0.260 \\
\hline IC regimen; TP vs. TPF & $1.630(1.151-2.308)$ & 0.006 \\
\hline \multicolumn{3}{|l|}{ Overall survival } \\
\hline Age (y) ( $\geq 45$ vs. < 45) & $0.892(0.510-1.560)$ & 0.688 \\
\hline Gender(F vs. M) & $1.846(1.115-3.055)$ & 0.017 \\
\hline T category (3-4 vs. 1-2) & $0.967(0.475-2.177)$ & 0.927 \\
\hline N category (2-3 vs. $0-1)$ & $1.161(0.620-2.177)$ & 0.641 \\
\hline Overall stage (IVa-b vs. III) & $1.606(0.950-2.715)$ & 0.077 \\
\hline EBV DNA & $3.881(1.657-9.090)$ & 0.002 \\
\hline IC regimen; PF vs. TPF & $1.604(0.917-2.804)$ & 0.098 \\
\hline IC regimen; TP vs. TPF & $1.571(0.719-3.436)$ & 0.258 \\
\hline \multicolumn{3}{|c|}{ Locoregional relapse-free survival } \\
\hline Age (y) ( $\geq 45$ vs. $<45)$ & $1.525(0.872-2.668)$ & 0.139 \\
\hline Gender(F vs. M) & $0.970(0.631-1.492)$ & 0.891 \\
\hline T category (3-4 vs. 1-2) & $1.189(0.598-2.364)$ & 0.622 \\
\hline N category (2-3 vs. $0-1)$ & $0.890(0.542-1.462)$ & 0.645 \\
\hline Overall stage (IVa-b vs. III) & $1.240(0.798-1.928)$ & 0.339 \\
\hline EBV DNA & $1.672(0.983-2.843)$ & 0.058 \\
\hline IC regimen; PF vs. TPF & $1.157(0.709-1.887)$ & 0.559 \\
\hline IC regimen; TP vs. TPF & $1.298(0.711-2.369)$ & 0.395 \\
\hline \multicolumn{3}{|l|}{ Distant metastasis-free survival } \\
\hline Age (y) ( $\geq 45$ vs. < 45) & $1.592(1.051-2.411)$ & 0.028 \\
\hline Gender(F vs. M) & $0.951(0.694-1.303)$ & 0.756 \\
\hline T category (3-4 vs. 1-2) & $1.428(0.852-2.393)$ & 0.177 \\
\hline N category (2-3 vs. $0-1)$ & $1.706(1.118-2.606)$ & 0.013 \\
\hline Overall stage (IVa-b vs. III) & $1.488(1.071-2.068)$ & 0.018 \\
\hline EBV DNA & 1.424(0.980-2.069) & 0.063 \\
\hline IC regimen; PF vs. TPF & 1.349(0.940-1.936) & 0.104 \\
\hline IC regimen; TP vs. TPF & $1.692(1.115-2.569)$ & 0.013 \\
\hline
\end{tabular}

A Cox proportional hazards regression model was used to detect variables individually without adjustment. All variables were transformed into categorical variables. HRs were calculated for age (years) ( $\geq 45 \mathrm{vs}$. $<45)$, sex (female vs. male), T stage (T3-4 vs. T1-2), N stage (N2-3 vs. N0-1), plasma EBV DNA before the first treatment ( $\geq 1500$ copies/ml vs. $<1500$ copies $/ \mathrm{ml})$, overall stage (IVa-b vs. III), and IC regimen (PF vs. TPF, TP vs. TPF)

Abbreviations: $\mathrm{Cl}$ Confidence interval, EBV Epstein-Barr virus, IC Induction chemotherapy, TPF Taxanes plus cisplatin with fluorouracil, PF Cisplatin with fluorouracil, TP Taxanes with cisplatin 

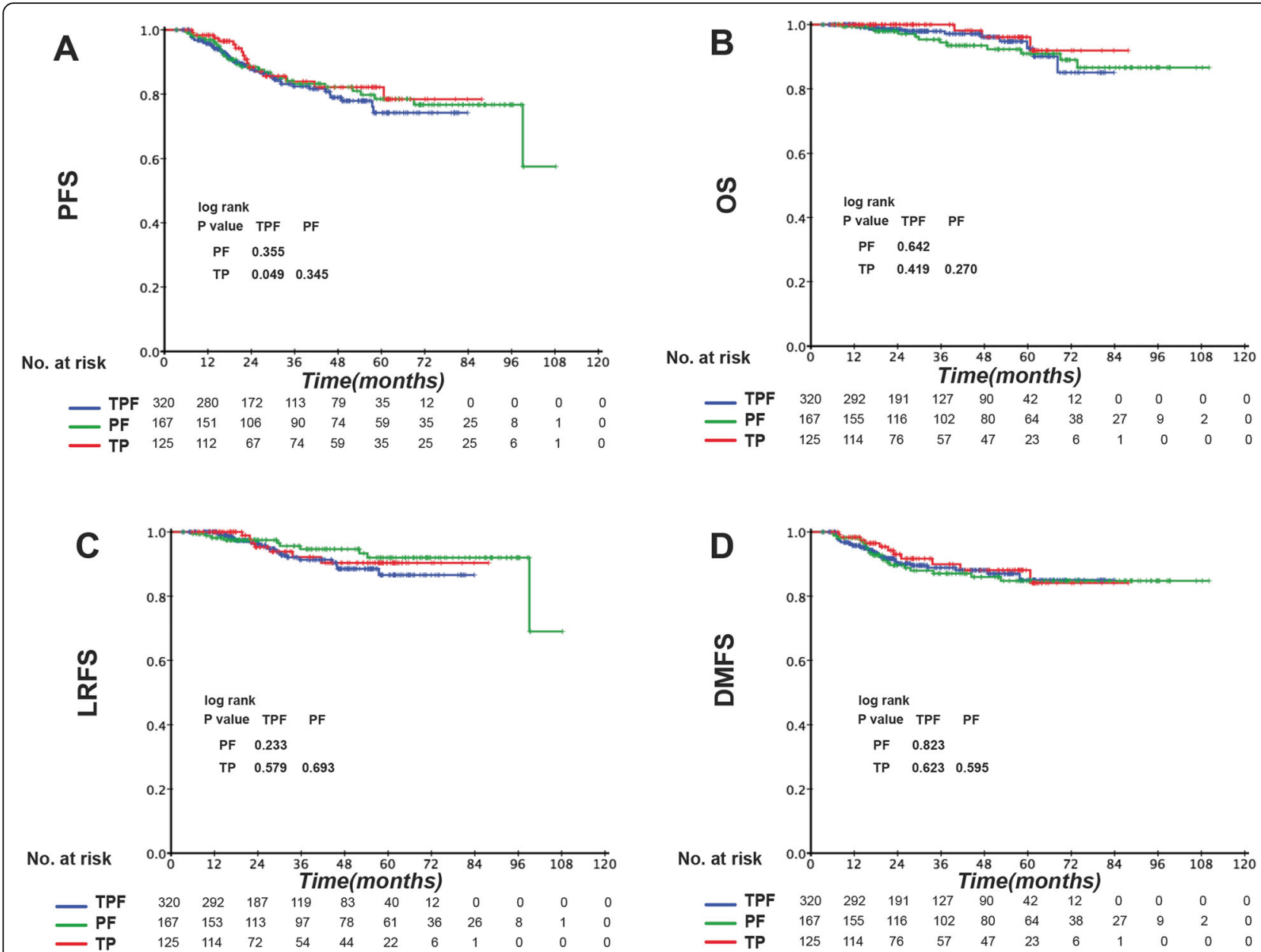

Fig. 2 Kaplan-Meier (a) progression-free survival (PFS), b overall survival (OS), c locoregional relapse-free survival (LRFS), and $\mathbf{d}$ distant metastasisfree survival (DMFS) curves for the 612 stage III NPC patients receiving induction TPF, PF, or TP

survival curves were superimposable (data not shown). However, in the high-risk group (pre-EBV DNA $\geq 1500$ copies), TPF was associated with significantly better PFS, OS, LRFS, and DMFS than were PF and TP. The 3-year PFS, OS, LRFS, and DMFS rates for TPF vs. PF vs. TP were $81.5 \%$ vs. $67.6 \%$ vs. $57.3 \%\left(\mathrm{P}_{\mathrm{TPF}}\right.$ vs. $\mathrm{PF}=0.019, \mathrm{P}_{\mathrm{TPF}}$ vs. $\mathrm{TP}<$ $0.001, \mathrm{P}_{\mathrm{PF} \text { vs. }}$ TP $=0.048$ Fig. $\left.4 \mathrm{a}\right), 97.3 \%$ vs. $86.6 \%$ vs. $85.8 \%$ $\left(\mathrm{P}_{\mathrm{TPF}}\right.$ vs. $\mathrm{PF}=0.012, \mathrm{P}_{\mathrm{TPF}}$ vs. TP $=0.031, \mathrm{P}_{\mathrm{PF}}$ vs. $\mathrm{TP}=0.954$ Fig. $4 \mathrm{~b}), 93.7 \%$ vs. $85.7 \%$ vs. $78.8 \%\left(\mathrm{P}_{\mathrm{TPF}}\right.$ vs. $\mathrm{PF}=0.040, \mathrm{P}_{\mathrm{TPF}}$ vs. TP $=0.021, \mathrm{P}_{\mathrm{PF}}$ vs. TP $=0.722$ Fig. $4 \mathrm{c}$ ), and $86.8 \%$ vs. $78.0 \%$ vs. $67.1 \%\left(\mathrm{P}_{\mathrm{TPF}}\right.$ vs. $\mathrm{PF}=0.025, \mathrm{P}_{\mathrm{TPF}}$ vs. $\mathrm{TP}=0.002, \mathrm{P}_{\mathrm{PF} \text { vs. } \mathrm{TP}}=$ 0.221 Fig. 4d) (Table 9 in Appendix 4).

As shown in Table 4, after adjusting for various factors, the IC regimen was established as an independent prognostic factor for PFS (PF vs. TPF: HR, 1.657; 95\% CI, $1.079-2.544 ; P=0.021$; TP vs. TPF: HR, 3.222; $95 \%$ CI, 1.917-5.416: $P<0.001$ ), OS (PF vs. TPF: HR, 2.608; 95\% CI, $1.180-5.762 ; P=0.018$; TP vs. TPF: HR, 3.117; 95\% CI, 1.051-9.244; $P=0.040$ ), and DMFS (PF vs. TPF: HR, 2.978; 95\% CI, $1.566-5.663 ; P=0.001$; TP vs. TPF:
HR, 1.724; 95\% CI, 1.076-2.763; $P=0.024)$. Clinical stage was also considered as a prognostic factor for DMFS.

\section{Acute toxicity profile}

In terms of acute toxicity during the IC period, patients in the TPF group experienced significantly more toxic effects than patients in the PF group, but similar toxic effects as patients in the TP group: leukocytopenia (grade 0-2: 75\% vs. $95.3 \%$ vs. $82.2 \%$; grade $3-4: 25.0 \%$ vs. $4.7 \%$ vs. $17.1 \%$; $P<0.001$ ) and neutropenia (grade $0-2: 57.4 \%$ vs. $87.1 \%$ vs. $64.5 \%$; grade $3-4: 42.6 \%$ vs. $12.9 \%$ vs. $35.5 \% ; P<0.001$ ). Intergroup differences in other acute toxicities such as anemia, ALT level increase, AST level increase, and BUN increase were not significant (Table 5).

\section{Discussion}

Distant metastasis remains a critical issue in cases of advanced NPC [23, 24], and IC could facilitate the eradication of micro-metastatic lesions and reduce locoregional failure. With the increasing evidence for the effectiveness of IC 

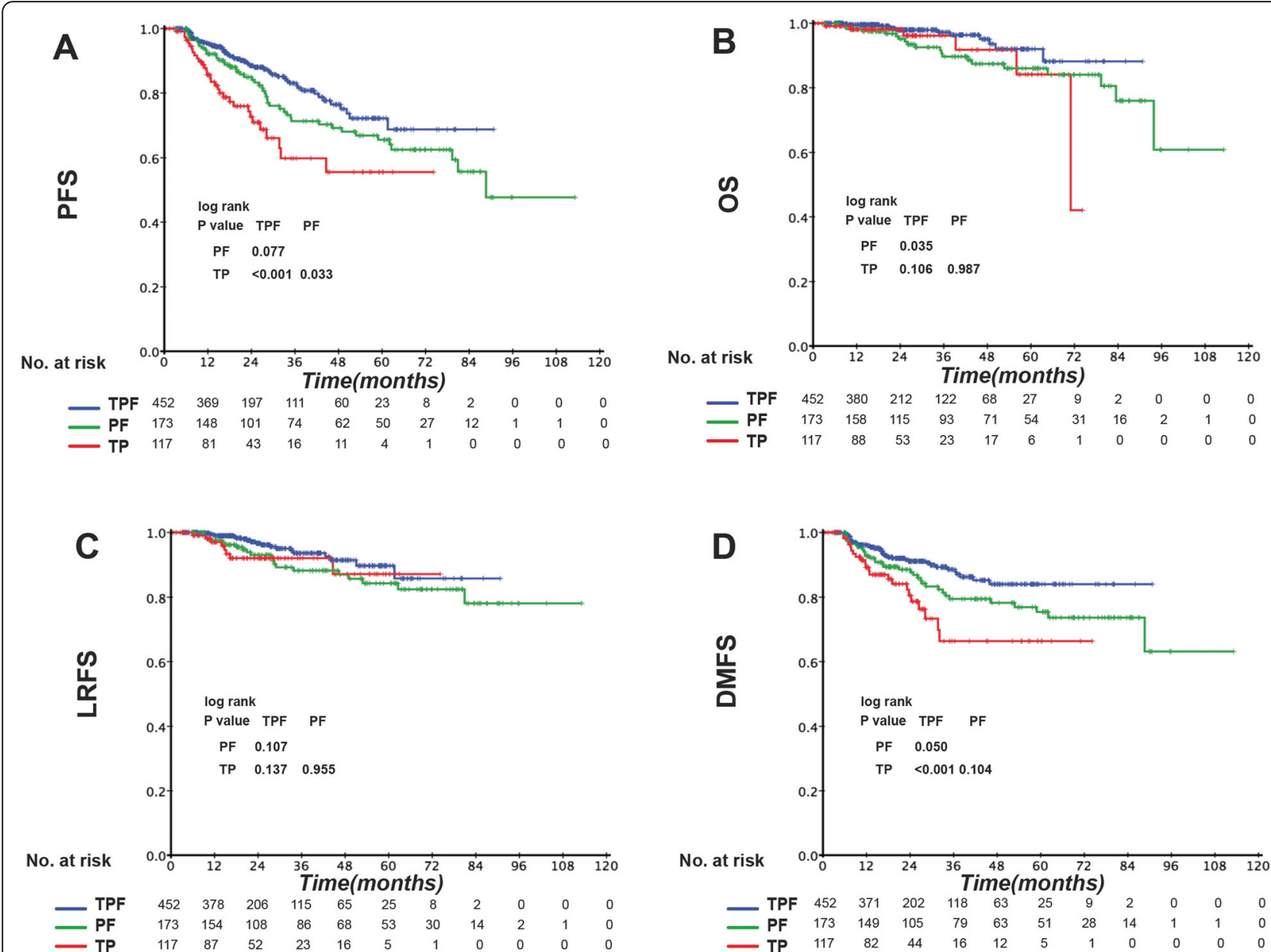

Fig. 3 Kaplan-Meier (a) progression-free survival (PFS), (b) overall survival (OS), c locoregional relapse-free survival (LRFS), and $\mathbf{d}$ distant metastasis-free survival (DMFS) curves for the 742 stage IVa-b NPC patients receiving induction TPF, PF, or TP

followed by CCRT for advanced NPC [10, 25-28], IC is being widely used in clinical settings. TPF, PF, and TP are the three induction regimens most frequently used for advanced NPC worldwide, and all of them can improve survival in patients with locoregionally advanced NPC $[10,25$, 26]. Our study indicates that TPF is the best choice among these three induction regimens for lowering the distant metastasis rate and improving the overall survival (OS) rate in high-risk NPC patients (IVa-b NPC patients with EBV DNA $\geq 1500$ copies $/ \mathrm{ml}$ ).

Our data showed that most patients in the PF and TP groups were treated in the early years while the recent ones were distributed to the TPF group. The TPF IC regimen is commonly used in advanced head and neck cancer $[29,30]$. In comparison with the standard PF regimen, regimens including taxanes, which are microtubule-stabilizing drugs that have been extensively used as effective chemotherapeutic agents for solid tumor treatment [31], showed significantly better PFS and OS and higher CR rates in head and neck cancers [29, 30, 32]. In another study, TPF demonstrated long-term survival benefits over PF in locally advanced head and neck cancer [33]. Long-term follow-up data confirm that TPF could increase larynx preservation and larynx dysfunction-free survival [34]. Undoubtedly, these benefits may also apply to NPC. Compared with the TP regimen, regimens including fluorouracil may also provide therapeutic gains. Lee et al. [35] found that the fluorouracil dose during the adjuvant phase was associated with significantly improved distant failure-free survival in a combined analysis of NPC-9901 and NPC-9902. This effect may also be present in the induction phase. Therefore, a combination of these three active agents seems to be the most effective regimen to provide optimal therapeutic benefit. Based on the above reasons, more clinicians preferred to select the TPF regimen recently.

Previous studies have suggested that TPF is superior to TP and PF for NPC patients. One report [16] demonstrated that the TP regimen may be sufficient for patients receiving a $C C D \geq 200 \mathrm{mg} / \mathrm{m}^{2}$, while $\mathrm{TPF}$ may be superior to TP and PF for patients receiving a $\mathrm{CCD}<$ 

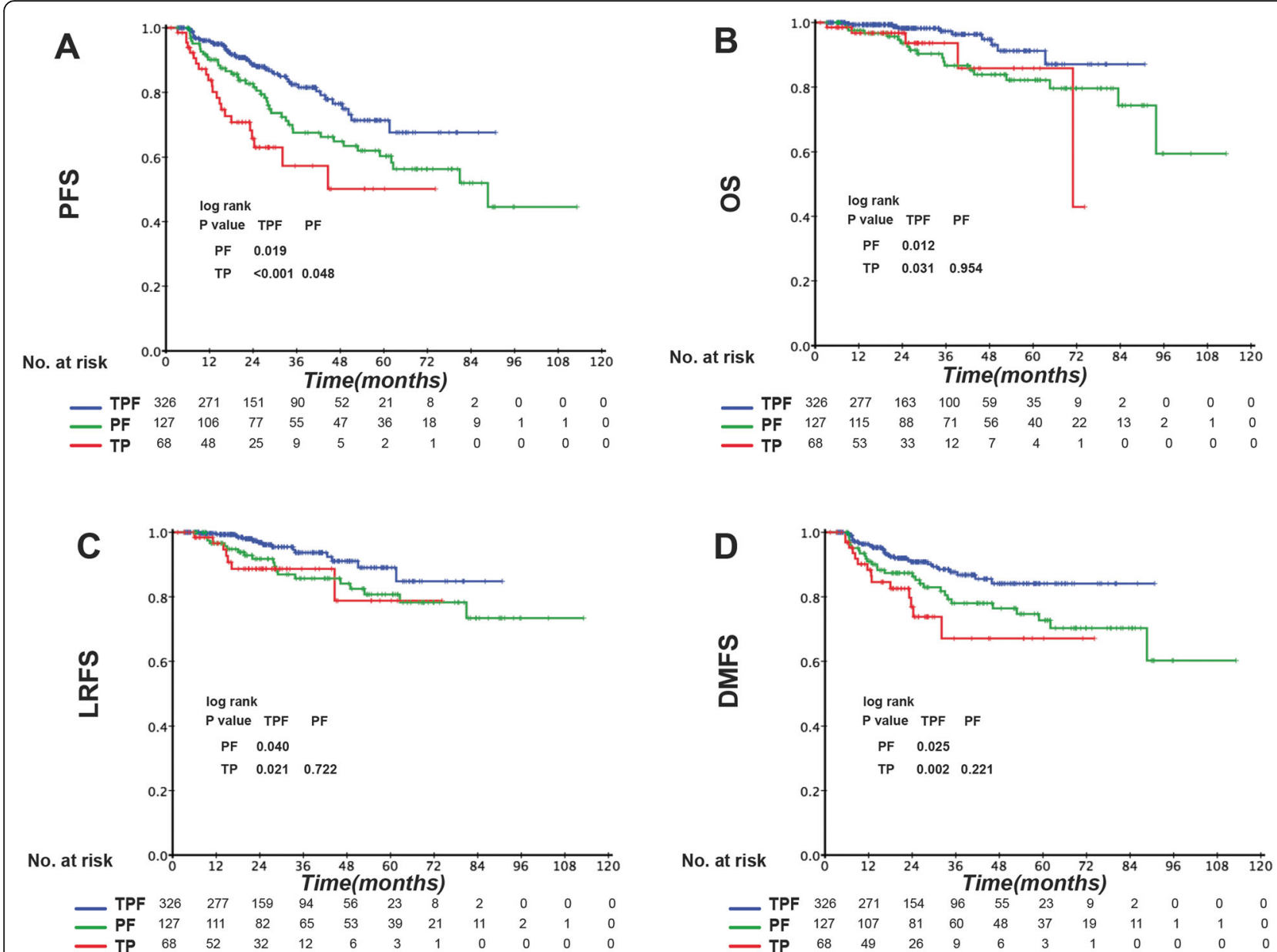

Fig. 4 Kaplan-Meier (a) progression-free survival (PFS), (b) overall survival (OS), (c), locoregional relapse-free survival (LRFS), and (d) distant metastasis-free survival (DMFS) curves for the 521 stage IVa-b patients with EBV $\geq 1500$ copies/ml NPC patients receiving induction TPF, PF, or TP

$200 \mathrm{mg} / \mathrm{m}^{2}$. In Liu's study [36], the TPF regimen yielded better long-term survival for patients with locoregionally advanced NPC in comparison with the PF regimen. In another study [37], TPF showed an improved early response of lymph node size reduction in comparison with the PF and TP regimens. These findings support the results of the present study, in which IC with TPF showed the best short-term tumor response and provided survival benefits compared with those of TP in all cases of locally advanced nasopharyngeal carcinoma.

However, one of the major limitations of previous studies was that they did not present data for plasma EBV DNA levels, which is an important prognostic factor for NPC patients and, in combination with the TNM stage, could identify patients with locoregionally advanced NPC who are at a high risk of locoregional recurrence and distant metastasis [17]. In a subgroup analysis stratified by clinical stage and EBV DNA levels, we observed an interesting scenario. Among patients with stage III NPC, survival outcomes were comparable between the three groups. However, among patients with stage IVa-b NPC, TPF could not only reduce distant metastasis but also prolong PFS and OS in comparison with TP and PF. Thus, TPF could reduce distant metastasis and improve the local control rate for patients (IVa-b) with a high tumor burden in comparison with TP and PF. A subgroup analysis of stage IVa-b NPC patients stratified by EBV DNA levels showed no survival benefit of TPF over PF and TP among low-risk patients (IVa-b with EBV DNA < 1500 copies/ml). However, in high-risk patients (IVa-b with EBV DNA $\geq 1500$ copies/ml), TPF achieved the best outcomes among the three induction regimens for improving the survival rate and lowering the distant metastasis rate. Hence, the more effective regimen, TPF, is particularly important for high-risk (IVa-b with EBV DNA $\geq 1500$ copies/ ml) patients.

Obviously, a combination of three agents produced more grade 3-4 toxicities. Notably, leukocytopenia and neutropenia were significantly higher in the TPF arm (25.0 and $42.6 \%$, respectively) and TP arm (17.1 and 35.5\%, respectively) than in the PF arm (4.7 and $12.9 \%$, respectively), 
Table 4 Multivariable analysis of prognostic factors for IVa-b patients with EBV DNA level $\geq 1500$ copies $/ \mathrm{ml}$

\begin{tabular}{|c|c|c|}
\hline & Hazard ratio* $(95 \% \mathrm{Cl})$ & $P$ value \\
\hline \multicolumn{3}{|l|}{ Progression-free survival } \\
\hline Age (y) ( $\geq 45$ vs. $<45$ ) & $1.171(0.802-1.710)$ & 0.414 \\
\hline Gender(F vs. M) & $1.421(0.857-2.357)$ & 0.173 \\
\hline Clinical stage (IVb vs. IVa) & $1.275(0.870-1.870)$ & 0.213 \\
\hline IC regimen; PF vs. TPF & $1.657(1.079-2.544)$ & 0.021 \\
\hline IC regimen; TP vs. TPF & $3.222(1.917-5.416)$ & $<0.001$ \\
\hline \multicolumn{3}{|l|}{ Overall survival } \\
\hline Age (y) ( $\geq 45$ vs. $<45$ ) & $1.895(0.941-3.817)$ & 0.074 \\
\hline Gender(F vs. M) & $0.689(0.320-1.485)$ & 0.342 \\
\hline Clinical stage (IVb vs. IVa) & $0.814(0.401-1.651)$ & 0.568 \\
\hline IC regimen; PF vs. TPF & $2.608(1.180-5.762)$ & 0.018 \\
\hline IC regimen; TP vs. TPF & $3.117(1.051-9.244)$ & 0.040 \\
\hline \multicolumn{3}{|c|}{ Locoregional relapse-free survival } \\
\hline Age (y) ( $\geq 45$ vs. $<45$ ) & $0.868(0.466-1.617)$ & 0.594 \\
\hline Gender(F vs. M) & $1.513(0.635-3.603)$ & 0.350 \\
\hline Clinical stage (IVb vs. IVa) & 0.919(0.490-1.724) & 0.792 \\
\hline IC regimen; PF vs. TPF & $2.091(1.043-4.191)$ & 0.038 \\
\hline IC regimen; TP vs. TPF & $2.626(0.490-1.724)$ & 0.037 \\
\hline \multicolumn{3}{|l|}{ Distant metastasis-free survival } \\
\hline Age (y) ( $\geq 45$ vs. $<45)$ & $1.103(0.692-1.756)$ & 0.680 \\
\hline Gender(F vs. M) & $1.210(0.675-2.171)$ & 0.522 \\
\hline Clinical stage (IVb vs. IVa) & $1.762(1.046-2.967)$ & 0.033 \\
\hline IC regimen; PF vs. TPF & $2.978(1.566-5.663)$ & 0.001 \\
\hline IC regimen; TP vs. TPF & $1.724(1.076-2.763)$ & 0.024 \\
\hline
\end{tabular}

Abbreviations: $\mathrm{Cl}$ Confidence interval, IC Induction chemotherapy, TPF Taxanes plus cisplatin with fluorouracil, $P F$ Cisplatin with fluorouracil, $T P=$ Taxanes with cisplatin

A Cox proportional hazards regression model was used to detect variables individually without adjustment. All variables were transformed into categorical variables. HRs were calculated for age (years) $(\geq 45$ vs. $<45$ years), sex (female vs. male), clinical stage (IVb vs. IVa), and IC regimen (PF vs. TPF, TP vs. TPF) whereas other toxicities were common in the three arms. This difference should be attributable to taxanes since the most common adverse event after taxane therapy is myelosuppression. Finally, the results showed that survival outcomes were comparable between the three groups in lowrisk NPC patients (stage III and IVa-b with EBV DNA < 1500 copies/ml), and the incidences of leukocytopenia and neutropenia were lower in the PF arm than in the TPF and TP arms. These findings indicate that PF-based IC has similar efficacy to TPF and TP in low-risk NPC patients (stage III and IVa-b with EBV DNA $<1500$ copies/ml) but is associated with fewer grade $3 / 4$ acute toxicities.

The data reported in this article also have several limitations. First, there was an inevitable bias caused by the retrospective nature of this study. Because of the selective bias, there were certain clinicopathologic differences among the patients receiving different IC regimens. Besides, the follow-up periods were also various in different IC groups. Although all potential prognostic factors were included in the multivariate analyses to avoid confounding effects, the credibility of our conclusions was still affected to some extent. Second, although our cohort is likely to be representative of the majority of patients diagnosed with NPC in South China, this was a singlecenter study. A multi-center study is needed to fully compare different IC regimens for locoregionally advanced nasopharyngeal carcinoma.

\section{Conclusions}

In summary, our study concluded that an induction TPF regimen was superior to $\mathrm{TP}$ and $\mathrm{PF}$ regimens for highrisk (IVa-b with EBV DNA $\geq 1500$ copies/ml) NPC, although grade 3-4 toxic events were more common but tolerable in the TPF arm. However, PF-based IC has similar efficacy to TPF and TP in low-risk NPC patients (stage III and IVa-b with EBV DNA $<1500$ copies $/ \mathrm{ml}$ ) but is associated with fewer grade $3 / 4$ acute toxicities. Further studies are needed to validate our findings.

Table 5 Grade 3-4 acute toxicities due to IC between the three arms

\begin{tabular}{|c|c|c|c|c|c|c|c|}
\hline \multirow{2}{*}{$\begin{array}{l}\text { Adverse event } \\
\text { (toxicity grade) }\end{array}$} & \multicolumn{2}{|c|}{$\operatorname{TPF}(n=772)$} & \multicolumn{2}{|c|}{$\operatorname{PF}(n=340)$} & \multicolumn{2}{|c|}{$\operatorname{TP}(\mathrm{n}=242)$} & \multirow[t]{2}{*}{$P$} \\
\hline & $0-2(\%)$ & $3-4(\%)$ & $0-2(\%)$ & $3-4(\%)$ & $0-2(\%)$ & $3-4(\%)$ & \\
\hline Leukocytopenia & $579(75.0)$ & 193(25.0) & $324(95.3)$ & $16(4.7)$ & 199(82.2) & $43(17.1)$ & $<0.001^{a}$ \\
\hline Neutropenia & $443(57.4)$ & $329(42.6)$ & 296(87.1) & $44(12.9)$ & $156(64.5)$ & $86(35.5)$ & $<0.001^{\mathrm{a}}$ \\
\hline Anemia & 763(98.8) & $9(1.2)$ & 339(99.7) & $1(0.3)$ & 240(99.2) & $2(0.8)$ & $0.441^{b}$ \\
\hline Thrombocytopenia & 765(99.1) & $7(0.9)$ & 338(99.4) & $2(0.6)$ & 239(98.8) & $3(1.2)$ & $0.672^{b}$ \\
\hline ALT increase & 763(99.0) & $8(1.0)$ & $337(99.1)$ & $3(0.9)$ & 239(98.8) & $3(1.2)$ & $0.871^{b}$ \\
\hline AST increase & $771(99.9)$ & $1(0.1)$ & 339(99.7) & $1(0.3)$ & 241(99.6) & $1(0.4)$ & $0.395^{b}$ \\
\hline Creatinine increase & 771(99.9) & $1(0.1)$ & 339(99.7) & $1(0.3)$ & $242(100)$ & $0(0.0)$ & $0.675^{b}$ \\
\hline BUN increase & $771(99.9)$ & $1(0.1)$ & $340(100)$ & $\mathrm{O}(0.0)$ & 240(99.2) & $2(0.8)$ & $0.134^{b}$ \\
\hline
\end{tabular}

Abbreviations: IC Induction chemotherapy, TPF Taxanes plus cisplatin with fluorouracil, PF Cisplatin with fluorouracil, TP Taxanes with cisplatin, ALT Alanine aminotransferase, AST Aspartate aminotransferase, BUN blood urea nitrogen

${ }^{\mathrm{a}} P$ values were calculated by Chi-square test. ${ }^{\mathrm{b}} P$ value calculated with Fisher's exact test 


\section{Appendix 1}

Table 6 Three-year PFS, OS, LRFS, DMFS based on different IC regimens in III-IVb patients

\begin{tabular}{|c|c|c|c|c|}
\hline & $\begin{array}{l}\operatorname{TPF}(\%) \\
n=772\end{array}$ & $\begin{array}{l}\operatorname{PF}(\%) \\
n=340\end{array}$ & $\begin{array}{l}\text { TP (\%) } \\
n=242\end{array}$ & $P$ value \\
\hline \multicolumn{5}{|c|}{ Progression-free survival } \\
\hline Failures & $108(14.0 \%)$ & $42(22.6 \%)$ & 47 (19.4\%) & 0.127 \\
\hline $\begin{array}{l}\text { Rate at } \\
3 \text { years }\end{array}$ & $\begin{array}{l}82.4 \% \\
(78.9-85.9)\end{array}$ & $\begin{array}{l}77.4 \% \\
(72.3-82.5)\end{array}$ & $\begin{array}{l}73.8 \% \\
(66.7-80.9)\end{array}$ & \\
\hline \multicolumn{5}{|l|}{ Overall survival } \\
\hline Deaths & $23(3.0 \%)$ & $32(9.4 \%)$ & $9(3.7 \%)$ & 0.029 \\
\hline $\begin{array}{l}\text { Rate at } \\
3 \text { years }\end{array}$ & $\begin{array}{l}97.2 \% \\
(95.6-98.8)\end{array}$ & $\begin{array}{l}92.1 \% \\
(88.8-95.4)\end{array}$ & $\begin{array}{l}97.0 \% \\
(93.9-100)\end{array}$ & \\
\hline \multicolumn{5}{|c|}{ Locoregional relapse-free survival } \\
\hline $\begin{array}{l}\text { Locoregional } \\
\text { failure }\end{array}$ & $40(5.2 \%)$ & $30(8.8 \%)$ & $15(6.2 \%)$ & 0.835 \\
\hline $\begin{array}{l}\text { Rate at } \\
3 \text { years }\end{array}$ & $\begin{array}{l}92.5 \% \\
(90.0-95.0)\end{array}$ & $\begin{array}{l}91.5 \% \\
(88.0-95.0)\end{array}$ & $\begin{array}{l}91.7 \% \\
(87.2-96.2)\end{array}$ & \\
\hline \multicolumn{5}{|c|}{ Distant metastasis-free survival } \\
\hline $\begin{array}{l}\text { Distant } \\
\text { failures }\end{array}$ & $72(9.3 \%)$ & $53(15.6 \%)$ & $33(13.6 \%)$ & 0.103 \\
\hline $\begin{array}{l}\text { Rate at } \\
3 \text { years }\end{array}$ & $\begin{array}{l}88.4 \% \\
(85.7-91.1)\end{array}$ & $\begin{array}{l}83.3 \% \\
(78.8-87.8)\end{array}$ & $\begin{array}{l}80.7 \% \\
(74.0-87.4)\end{array}$ & \\
\hline
\end{tabular}

Data are $n(\%)$ or rate $(95 \% \mathrm{Cl}) . P$ values were calculated with the unadjusted log-rank test

\section{Appendix 2}

Table 7 Multivariable analysis of prognostic factors for III-IVb NPC patients treated with PF regimen

\begin{tabular}{|c|c|c|}
\hline & HR $(95 \% \mathrm{Cl})$ & $P$-value value \\
\hline \multicolumn{3}{|l|}{ Progression-free survival } \\
\hline Age (y) ( $\geq 45$ vs. $<45$ ) & $1.319(0.839-2.074)$ & 0.231 \\
\hline Gender (F vs. M) & $1.496(0.844-2.651)$ & 0.168 \\
\hline T category (3-4 vs. 1-2) & $1.556(0.755-3.208)$ & 0.231 \\
\hline N category (2-3 vs. $0-1)$ & $1.736(0.897-3.361)$ & 0.101 \\
\hline Overall stage (IVa-b vs. III) & $1.711(1.047-2.796)$ & 0.032 \\
\hline EBV DNA (< 1500 vs. $\geq 1500)$ & $2.327(1.223-4.427)$ & 0.010 \\
\hline RT method (IMRT vs. 2D-RT) & $1.159(0.910-1.477)$ & 0.232 \\
\hline \multicolumn{3}{|l|}{ Overall survival } \\
\hline Age (y) ( $\geq 45$ vs. $<45$ ) & $2.067(0.986-4.33)$ & 0.054 \\
\hline Gender (F vs. M) & $0.710(0.329-1.535)$ & 0.384 \\
\hline T category (3-4 vs. 1-2) & $0.921(0.335-2.533)$ & 0.874 \\
\hline N category (2-3 vs. 0-1) & $1.150(0.446-2.966)$ & 0.772 \\
\hline Overall stage (IVa-b vs. III) & $1.998(0.911-4.384)$ & 0.084 \\
\hline EBV DNA (< 1500 vs. $\geq 1500)$ & $5.091(1.209-21.430)$ & 0.027 \\
\hline RT method (IMRT vs. 2D-RT) & $0.875(0.660-1.290)$ & 0.244 \\
\hline \multicolumn{3}{|l|}{ Locoregional relapse-free survival } \\
\hline Age (y) ( $\geq 45$ vs. $<45$ ) & $1.035(0.500-2.140)$ & 0.927 \\
\hline Gender (F vs. M) & $0.866(0.378-1.986)$ & 0.734 \\
\hline T category (3-4 vs. 1-2) & $1.136(0.371-3.479)$ & 0.823 \\
\hline N category (2-3 vs. $0-1)$ & $0.812(0.334-1.975)$ & 0.646 \\
\hline Overall stage (IVa-b vs. III) & $2.002(0.890-4.502)$ & 0.093 \\
\hline EBV DNA (< 1500 vs. $\geq 1500)$ & $3.431(1.032-11.400)$ & 0.044 \\
\hline RT method (IMRT vs. 2D-RT) & $1.213(0.818-1.801)$ & 0.337 \\
\hline \multicolumn{3}{|l|}{ Distant metastasis-free survival } \\
\hline Age (y) ( $\geq 45$ vs. $<45$ ) & $0.913(0.531-1.571)$ & 0.742 \\
\hline Gender ( $F$ vs. M) & $2.125(0.993-4.548)$ & 0.052 \\
\hline T category (3-4 vs. 1-2) & $2.041(0.791-5.265)$ & 0.140 \\
\hline N category (2-3 vs. 0-1) & $2.353(0.984-5.626)$ & 0.054 \\
\hline Overall stage (IVa-b vs. III) & $1.619(0.902-2.905)$ & 0.107 \\
\hline EBV DNA (< 1500 vs. $\geq 1500)$ & $1.912(0.927-3.946)$ & 0.079 \\
\hline RT method (IMRT vs. 2D-RT) & $1.242(0.919-1.679)$ & 0.158 \\
\hline
\end{tabular}

A Cox proportional hazards regression model was used to detect variables individually without adjustment. All variables were transformed into categorical variables. HRs were calculated for age (years) $(\geq 45$ vs. $<45)$, sex (female vs. male), T stage (T3-4 vs. T1-2), N stage (N2-3 vs. N0-1), plasma EBV DNA before the first treatment ( $\geq 1500$ copies $/ \mathrm{ml} \mathrm{vs.}<1500$ copies $/ \mathrm{ml}$ ), overall stage (IVa-b vs. III), and RT method (IMRT vs. 2D-RT) Abbreviations: $C I$ Confidence interval, EBV Epstein-Barr virus, PF Cisplatin with fluorouracil 


\section{Appendix 3}

Table 8 Patient demographics and clinical characteristics

\begin{tabular}{|c|c|c|c|c|c|c|c|c|}
\hline \multirow[b]{2}{*}{ Characteristic } & \multirow[b]{2}{*}{$\begin{array}{l}\operatorname{TPF}(n=320) \\
\text { No. }(\%)\end{array}$} & \multicolumn{4}{|l|}{ III } & \multicolumn{3}{|l|}{ IVA-IVB } \\
\hline & & $\begin{array}{l}\operatorname{PF}(n=167) \\
\text { No. }(\%)\end{array}$ & $\begin{array}{l}\operatorname{TP}(n=125) \\
\text { No. }(\%)\end{array}$ & P & $\begin{array}{l}\operatorname{TPF}(n=452) \\
\text { No. }(\%)\end{array}$ & $\begin{array}{l}\operatorname{PF}(n=173) \\
\text { No. }(\%)\end{array}$ & $\begin{array}{l}\mathrm{TP}(n=117) \\
\text { No. }(\%)\end{array}$ & $P$ \\
\hline Age, y & & & & $0.106^{a}$ & & & & $0.865^{a}$ \\
\hline Median (range) & $42(13-70)$ & $44(18-68)$ & $46(19-64)$ & & $45(8-74)$ & $45(15-71)$ & $46(18-71)$ & \\
\hline$<45$ & 186(58.1) & $89(53.3)$ & $59(47.2)$ & & 225(49.8) & $82(47.4)$ & $57(48.7)$ & \\
\hline$\geq 45$ & 134(41.9) & $78(46.7)$ & $66(52.8)$ & & $227(50.2)$ & $91(52.6)$ & $60(51.3)$ & \\
\hline Gender & & & & $0.151^{a}$ & & & & $0.668^{a}$ \\
\hline Female & $78(24.4)$ & $53(31.7)$ & $29(26.1)$ & & $106(23.5)$ & $38(22.0)$ & $31(26.5)$ & \\
\hline Male & $242(75.6)$ & 114(68.3) & $96(76.8)$ & & $346(76.5)$ & 135(78.0) & $86(73.5)$ & \\
\hline Pathological type & & & $0.660^{b}$ & & & & $0.370^{b}$ & \\
\hline WHO type I & $0(0)$ & $0(0)$ & $0(0)$ & & $3(0.7)$ & $1(0.6)$ & $0(0)$ & \\
\hline WHO type II & $2(0.6)$ & $2(1.2)$ & $0(0)$ & & $2(0.4)$ & $3(1.7)$ & $0(0)$ & \\
\hline WHO type III & 318(99.4) & 165(98.8) & $125(100)$ & & 447(98.9) & 169(97.7) & 117(100) & \\
\hline T stage ${ }^{c}$ & & & & $0.049^{b}$ & & & & $0.426^{a}$ \\
\hline $\mathrm{T} 1$ & $4(1.3)$ & $3(1.8)$ & $1(0.8)$ & & $7(1.5)$ & $2(1.2)$ & $1(0.9)$ & \\
\hline $\mathrm{T} 2$ & $41(12.8)$ & $38(22.8)$ & 23(18.4) & & $30(6.6)$ & $11(6.4)$ & $6(5.1)$ & \\
\hline T3 & 275(85.9) & 126(75.4) & $101(80.8)$ & & 104(48.1) & 168(48.4) & 118(47.6) & \\
\hline T4 & $0(0)$ & $0(0)$ & $0(0)$ & & $311(39.5)$ & 118(34.0) & $93(37.5)$ & \\
\hline N stage ${ }^{c}$ & & & & $<0.001^{\mathrm{a}}$ & & & & $0.047^{a}$ \\
\hline No & $6(1.9)$ & $1(0.6)$ & $5(4.0)$ & & $9(2.0)$ & $10(5.8)$ & $4(3.4)$ & \\
\hline N1 & $95(29.7)$ & $17(10.2)$ & $32(25.6)$ & & $98(21.7)$ & $40(23.1)$ & $33(28.2)$ & \\
\hline N2 & 219(68.4) & 149(89.2) & $88(70.4)$ & & $148(432.7)$ & $48(27.7)$ & $43(36.8)$ & \\
\hline N3 & $0(0)$ & $0(0)$ & $0(0)$ & & 197(43.6) & $75(43.4)$ & $37(31.6)$ & \\
\hline EBV DNA & & & & $0.085^{a}$ & & & & $0.007^{a}$ \\
\hline$\geq 1500$ & 188(58.8) & 104(62.3) & $62(49.6)$ & & $326(72.1)$ & $127(73.4)$ & $68(58.1)$ & \\
\hline$<1500$ & $132(41.3)$ & $63(37.7)$ & $63(50.4)$ & & $126(27.9)$ & $46(26.6)$ & 49(41.9) & \\
\hline RT technique & & & $<0.001^{\mathrm{a}}$ & & & & $<0.001^{b}$ & \\
\hline 2D RT & $5(1.6)$ & $52(31.1)$ & $9(7.2)$ & & $2(0.4)$ & $49(28.3)$ & $2(1.7)$ & \\
\hline IMRT & 315(98.4) & 115(68.9) & 116(92.8) & & 450(99.6) & $124(71.7)$ & 115(98.3) & \\
\hline CCD (mg/m2) & & & & $0.032^{a}$ & & & & $0.791^{a}$ \\
\hline Median (range) & 160(68-300) & $160(40-250)$ & $160(60-300)$ & & $160(25-300)$ & $160(50-240)$ & $160(20-300)$ & \\
\hline$\geq 200$ & $85(26.6)$ & $27(16.3)$ & $27(21.6)$ & & $98(21.7)$ & $36(20.8)$ & $22(18.8)$ & \\
\hline$<200$ & $235(73.4)$ & $140(83.8)$ & 98(78.4) & & $354(78.3)$ & 137(79.2) & $95(81.2)$ & \\
\hline
\end{tabular}

Abbreviations: TPF Taxanes plus cisplatin with fluorouracil, PF Cisplatin with fluorouracil, TP Taxanes with cisplatin, EBV Epstein-Barr virus, CCD Cumulative cisplatin dose during radiotherapy

${ }^{\mathrm{a}} P$ values were calculated by the Chi-square test. ${ }^{\mathrm{b}} P$ value calculated with Fisher's exact test

${ }^{\mathrm{C}}$ According to the 7 th edition of the UICC/AJCC staging system 


\section{Appendix 4}

Table 9 Three-year PFS, OS, DMFS, LRFS based on different IC regimens in IVa-b patients of EBV $\geq 1500$ copies $/ \mathrm{ml}$

\begin{tabular}{|c|c|c|c|c|}
\hline & $\operatorname{TPF}(\%) n=326$ & $\mathrm{PF}(\%) n=127$ & $\mathrm{TP}(\%) n=68$ & $P$ value \\
\hline \multicolumn{5}{|l|}{ Progression-free survival } \\
\hline Failures & $46(14.1 \%)$ & $42(33.0 \%)$ & $22(32.4 \%)$ & \multirow[t]{2}{*}{$<0.001$} \\
\hline Rate at 3 years & $81.5 \%(75.6-87.4)$ & $67.6 \%(58.2-77.0)$ & $57.3 \%(41.0-73.6)$ & \\
\hline \multicolumn{5}{|l|}{ Overall survival } \\
\hline Deaths & $10(3.1 \%)$ & 19 (15.0\%) & $5(7.3 \%)$ & \multirow[t]{2}{*}{0.029} \\
\hline Rate at 3 years & $97.3 \%(94.8-99.8)$ & $86.6 \%(79.7-93.5)$ & $85.8 \%(69.7-102)$ & \\
\hline \multicolumn{5}{|c|}{ Locoregional relapse-free survival } \\
\hline Locoregional failure & $15(4.6 \%)$ & 19 (15.0\%) & $7(10.3 \%)$ & \multirow[t]{2}{*}{0.032} \\
\hline Rate at 3 years & $93.7 \%(90.0-97.4)$ & $85.7 \%(78.6-92.8)$ & $78.8 \%(59.0-98.6)$ & \\
\hline \multicolumn{5}{|c|}{ Distant metastasis-free survival } \\
\hline Distant failures & $31(9.5 \%)$ & $28(22.0 \%)$ & $14(20.6 \%)$ & \multirow[t]{2}{*}{0.003} \\
\hline Rate at 3 years & $86.8 \%(81.9-91.7)$ & $78.0 \%(69.8-86.2)$ & $67.1 \%(49.9-84.3)$ & \\
\hline
\end{tabular}

Data are $n(\%)$ or rate $(95 \% \mathrm{Cl})$. $P$ values were calculated with the unadjusted log-rank test

\section{Abbreviations}

2D-CRT: Two-dimensional radiotherapy; CCD: Cumulative cisplatin dose; CCRT: Concurrent chemoradiotherapy; Cls: Confidence intervals; DMFS: Distant metastasis-free survival; EBV: Epstein-Barr Virus; HRs: Hazard ratios; IC: Induction chemotherapy; IMRT: Intensity-modulated radiotherapy; KPS: Karnofsky performance score; LRFS: Locoregional relapse-free survival; MRI: Magnetic resonance imaging; NPC: Nasopharyngeal carcinoma; OS: Overall survival; PET/CT: Positron emission tomography/computed tomography; PF: Cisplatin and 5-fuorouracil); PFS: Progression-free survival; RT: Radiotherapy; TP: Taxanes and cisplatin; TPF: Taxanes, cisplatin and 5fuorouracil; WHO: World Health Organization

\section{Acknowledgments}

We thank all the patients who participated in this study.

\section{Authors' contributions}

HQM, LG, and LQT carried out the study concepts; SLL, XSS, and HJX participated in study design; SLL, XSS, HJX, HL, YJL, XYL, JJY, CL, ZCY, SSG, LTL, YYD and QNT participated in data acquisition; SLL, XSS, HJX, HL, YJL, $X Y L, J J Y, Y Y D$ and $C L$ participated in quality control of data and algorithms; SLL, XSS, ZCY, SSG, LTL, YYD and QNT participated in data analysis and interpretation; SLL, XSS and HJX participated in statistical analysis; SLL, QYC and HXL participated in manuscript preparation; SLL, QYC and HXL participated in manuscript editing; HQM, LG and LQT participated in Manuscript review. All authors have read and approved the manuscript.

\section{Funding}

Design of the study: the National Key R\&D Program of China [grant numbers 2016YFC0902003, 2017YFC1309003, 2017YFC0908500], the National Natural Science Foundation of China [grant numbers 81425018, 81672868, 81602371, $81802775,81572848,81772877,81372814,81773103]$, the Sun Yat-sen University Clinical Research 5010 Program, the Sci-Tech Project Foundation of Guangzhou City [grant number 201707020039], the National Key Basic Research Program of China [grant number 2013CB910304], the Sun Yat-sen University Clinical Research 5010 Program, the Special Support Plan of Guangdong Province [grant numbers 2014TX01R145].

Data collection, analysis and interpretation: the Natural Science Foundation of Guangdong Province (No. 2017A030312003, 2018A0303131004), the SciTech Project Foundation of Guangdong Province [grant numbers 2014A020212103, 2012B031800255, 2014A020212528], the Natural Science Foundation of Guangdong Province for Distinguished Young Scholar (No. 2018B030306001), Pearl River S\&T Nova Program of Guangzhou (No. 201806010135), the Guangzhou Science and Technology Planning Project, China [grant number 2014 J4100181], the Health \& Medical Collaborative Innovation Project of Guangzhou City [grant number 201400000001, 201803040003].
Manuscript writing: the National Science \& Technology Pillar Program during the Twelfth Five-year Plan Period [grant number 2014BAI09B10], the PhD Start-up Fund of Natural Science Foundation of Guangdong Province, China [grant number 2016A030310221], the Cultivation Foundation for the Junior Teachers in Sun Yat-sen University [grant number 16ykpy28], the Planned Science and Technology Project of Guangdong Province (2019B020230002) and the Fundamental Research Funds for the Central Universities.

\section{Availability of data and materials}

The datasets used and/or analysed during the current study are available from the corresponding author on reasonable request.

\section{Ethics approval and consent to participate}

This retrospective study was approved by the Clinical Research Committee of Sun Yat-Sen University Cancer Center, China. All of the participants provided written informed consent before treatment.

\section{Consent for publication}

Not applicable.

\section{Competing interests}

The authors declare that they have no competing interests.

\section{Author details}

${ }^{1}$ Collaborative Innovation Center for Cancer Medicine, Guangdong Key Laboratory of Nasopharyngeal Carcinoma Diagnosis and Therapy, Sun Yat-sen University Cancer Center; State Key Laboratory of Oncology in South China, 651 Dongfeng Road East, Guangzhou 510060, People's Republic of China. ${ }^{2}$ Department of Nasopharyngeal Carcinoma, Sun Yat-sen University Cancer Center, 651 Dongfeng Road East, Guangzhou 510060, People's Republic of China. ${ }^{3}$ Department of Radiation Oncology, Sun Yat-sen University Cancer Center, 651 Dongfeng Road East, Guangzhou 510060, People's Republic of China.

Received: 13 March 2019 Accepted: 20 January 2020

Published online: 03 February 2020

\section{References}

1. Wee JT, Ha TC, Loong SL, Qian CN. Is nasopharyngeal cancer really a "Cantonese cancer"? Chin J Cancer. 2010;29(5):517-26.

2. Choa G. Nasopharyngeal carcinoma. Some observations on the clinical features and technique of examination. Pac Med Surg. 1967;75(3):172-4.

3. Peng G, Wang T, Yang K, Zhang S, Zhang T, Li Q, Han J, Wu G. A prospective, randomized study comparing outcomes and toxicities of intensity-modulated radiotherapy vs. conventional two-dimensional 
radiotherapy for the treatment of nasopharyngeal carcinoma. Radiother Oncol. 2012;104(3):286-93.

4. Zhang M, Li J, Shen G, Zou X, Xu J, Jiang R, You R, Hua Y, Sun Y, Ma J, et al. Intensity-modulated radiotherapy prolongs the survival of patients with nasopharyngeal carcinoma compared with conventional two-dimensional radiotherapy: a 10-year experience with a large cohort and long follow-up. Eur J Cancer. 2015;51(17):2587-95.

5. Yi J, Huang X, Gao L, Luo J, Zhang S, Wang K, Qu Y, Xiao J, Xu G. Intensitymodulated radiotherapy with simultaneous integrated boost for locoregionally advanced nasopharyngeal carcinoma. Radiat Oncol. 2014;9:56.

6. Tang L, Li C, Li J, Chen W, Chen Q, Yuan L, Lai X, He Y, Xu Y, Hu D, etal. Establishment and validation of prognostic nomograms for endemic nasopharyngeal carcinoma. J Natl Cancer Inst. 2016;108. https://doi.org/10. 1093/jnci/djv291.

7. Al-Sarraf M, LeBlanc M, Giri PG, Fu KK, Cooper J, Vuong T, Forastiere AA, Adams G, Sakr WA, Schuller DE, et al. Chemoradiotherapy versus radiotherapy in patients with advanced nasopharyngeal cancer: phase III randomized intergroup study 0099. J Clin Oncol. 1998;16(4):1310-7.

8. Lin JC, Jan JS, Hsu CY, Liang WM, Jiang RS, Wang WY. Phase III study of concurrent chemoradiotherapy versus radiotherapy alone for advanced nasopharyngeal carcinoma: positive effect on overall and progression-free survival. J Clin Oncol. 2003;21(4):631-7.

9. Hong R, Ting L, Ko J, Hsu M, Sheen T, Lou P, Wang C, Chung N, Lui L. Induction chemotherapy with mitomycin, epirubicin, cisplatin, fluorouracil, and leucovorin followed by radiotherapy in the treatment of locoregionally advanced nasopharyngeal carcinoma. J Clin Oncol. 2001;19(23):4305-13.

10. Hui E, Ma B, Leung S, King A, Mo F, Kam M, Yu B, Chiu S, Kwan W, Ho R, et al. Randomized phase II trial of concurrent cisplatin-radiotherapy with or without neoadjuvant docetaxel and cisplatin in advanced nasopharyngeal carcinoma. J Clin Oncol. 2009;27(2):242-9.

11. Airoldi M, Gabriele P, Gabriele A, Garzaro M, Raimondo L, Pedani F, Beatrice F, Pecorari G, Giordano C. Induction chemotherapy with carboplatin and taxol followed by radiotherapy and concurrent weekly carboplatin + taxol in locally advanced nasopharyngeal carcinoma. Cancer Chemother Pharmacol. 2011;67(5):1027-34.

12. Bossi P, Orlandi E, Bergamini C, Locati L, Granata R, Mirabile A, Parolini $D$, Franceschini M, Fallai C, Olmi P, et al. Docetaxel, cisplatin and 5-fluorouracilbased induction chemotherapy followed by intensity-modulated radiotherapy concurrent with cisplatin in locally advanced EBV-related nasopharyngeal cancer. Ann Oncol. 2011;22(11):2495-500.

13. OuYang P, Xie C, Mao Y, Zhang Y, Liang X, Su Z, Liu Q, Xie F. Significant efficacies of neoadjuvant and adjuvant chemotherapy for nasopharyngeal carcinoma by meta-analysis of published literature-based randomized, controlled trials. Ann Oncol. 2013;24(8):2136-46.

14. Boscolo-Rizzo P, Tirelli G, Mantovani M, Baggio V, Lupato V, Spinato G, Gava A, Da Mosto M. Non-endemic locoregionally advanced nasophanyngeal carcinoma: long-term outcome after induction plus concurrent chemoradiotherapy in everyday clinical practice. Eur Arch Otorhinolaryngol. 2015;272(11):3491-8.

15. Sun X, Zeng L, Chen C, Huang Y, Han F, Xiao W, Liu S, Lu T. Comparing treatment outcomes of different chemotherapy sequences during intensity modulated radiotherapy for advanced $\mathrm{N}$-stage nasopharyngeal carcinoma patients. Radiat Oncol. 2013;8:265

16. Peng $H$, Tang $L L$, Chen BB, Chen L, Li WF, Mao YP, Liu X, Zhang Y, Liu LZ, Tian $L$, et al. Optimizing the induction chemotherapy regimen for patients with locoregionally advanced nasopharyngeal carcinoma: a big-data intelligence platform-based analysis. Oral Oncol. 2018;79:40-6.

17. Lin JC, Wang WY, Chen KY, Wei YH, Liang WM, Jan JS, Jiang RS. Quantification of plasma Epstein-Barr virus DNA in patients with advanced nasopharyngeal carcinoma. N Engl J Med. 2004;350(24):2461-70.

18. Lee AW, Ngan RK, Tung SY, Cheng A, Kwong DL, Lu TX, Chan AT, Chan LL, Yiu H, Ng WT, et al. Preliminary results of trial NPC-0501 evaluating the therapeutic gain by changing from concurrent-adjuvant to inductionconcurrent chemoradiotherapy, changing from fluorouracil to capecitabine, and changing from conventional to accelerated radiotherapy fractionation in patients with locoregionally advanced nasopharyngeal carcinoma. Cancer. 2015;121(8):1328-38.

19. Lee A, Lau K, Hung W, Ng W, Lee M, Choi C, Chan C, Tung R, Cheng P, Yau T. Potential improvement of tumor control probability by induction chemotherapy for advanced nasopharyngeal carcinoma. Radiother Oncol. 2008;87(2):204-10.

20. Lin S, Lu JJ, Han L, Chen Q, Pan J. Sequential chemotherapy and intensitymodulated radiation therapy in the management of locoregionally advanced nasopharyngeal carcinoma: experience of 370 consecutive cases. BMC Cancer. 2010;10:39.

21. Yu Z, Luo W, Zhou QC, Zhang QH, Kang DH, Liu MZ. Impact of changing gross tumor volume delineation of intensity-modulated radiotherapy on the dose distribution and clinical treatment outcome after induction chemotherapy for the primary locoregionally advanced nasopharyngeal carcinoma. Ai Zheng. 2009;28(11):1132-7.

22. Therasse P, Arbuck SG, Eisenhauer EA, Wanders J, Kaplan RS, Rubinstein L, Verweij J, Van Glabbeke M, van Oosterom AT, Christian MC, et al. New guidelines to evaluate the response to treatment in solid tumors. European Organization for Research and Treatment of Cancer, National Cancer Institute of the United States, National Cancer Institute of Canada. J Natl Cancer Inst. 2000;92(3):205-16.

23. Lee N, Xia P, Quivey JM, Sultanem K, Poon I, Akazawa C, Akazawa P, Weinberg V, Fu KK. Intensity-modulated radiotherapy in the treatment of nasopharyngeal carcinoma: an update of the UCSF experience. Int J Radiat Oncol Biol Phys. 2002;53(1):12-22.

24. Sun X, Su S, Chen C, Han F, Zhao C, Xiao W, Deng X, Huang S, Lin C, Lu T. Long-term outcomes of intensity-modulated radiotherapy for 868 patients with nasopharyngeal carcinoma: an analysis of survival and treatment toxicities. Radiother Oncol. 2014;110(3):398-403.

25. Cao SM, Yang Q, Guo L, Mai HQ, Mo HY, Cao K, Qian CN, Zhao C, Xiang $Y Q$, Zhang XP, et al. Neoadjuvant chemotherapy followed by concurrent chemoradiotherapy versus concurrent chemoradiotherapy alone in locoregionally advanced nasopharyngeal carcinoma: A phase III multicentre randomised controlled trial. Eur J Cancer. 2017;75:14-23.

26. Sun Y, Li WF, Chen NY, Zhang N, Hu GQ, Xie FY, Sun Y, Chen XZ, Li JG, Zhu $X D$, et al. Induction chemotherapy plus concurrent chemoradiotherapy versus concurrent chemoradiotherapy alone in locoregionally advanced nasopharyngeal carcinoma: a phase 3, multicentre, randomised controlled trial. Lancet Oncol. 2016;17(11):1509-20.

27. Chua DT, Ma J, Sham JS, Mai HQ, Choy DT, Hong MH, Lu TX, Min HQ. Longterm survival after cisplatin-based induction chemotherapy and radiotherapy for nasopharyngeal carcinoma: a pooled data analysis of two phase III trials. J Clin Oncol. 2005;23(6):1118-24.

28. Blanchard P, Lee A, Marguet S, Leclercq J, Ng WT, Ma J, Chan AT, Huang PY, Benhamou E, Zhu G, et al. Chemotherapy and radiotherapy in nasopharyngeal carcinoma: an update of the MAC-NPC meta-analysis. Lancet Oncol. 2015;16(6):645-55.

29. Posner MR, Hershock DM, Blajman CR, Mickiewicz E, Winquist E, Gorbounova V, Tjulandin S, Shin DM, Cullen K, Ervin TJ, et al. Cisplatin and fluorouracil alone or with docetaxel in head and neck cancer. N Engl J Med. 2007;357(17):1705-15.

30. Vermorken JB, Remenar E, van Herpen C, Gorlia T, Mesia R, Degardin M, Stewart JS, Jelic S, Betka J, Preiss JH, et al. Cisplatin, fluorouracil, and docetaxel in unresectable head and neck cancer. N Engl J Med. 2007; 357(17):1695-704

31. Colevas AD, Posner MR. Docetaxel in head and neck cancer: a review. Am J Clin Oncol. 1998;21(5):482-6.

32. Hitt R, Lopez-Pousa A, Martinez-Trufero J, Escrig V, Carles J, Rizo A, Isla D, Vega ME, Marti IL, Lobo F, et al. Phase III study comparing cisplatin plus fluorouracil to paclitaxel, cisplatin, and fluorouracil induction chemotherapy followed by chemoradiotherapy in locally advanced head and neck cancer. J Clin Oncol. 2005;23(34):8636-45.

33. Lorch JH, Goloubeva O, Haddad Rl, Cullen K, Sarlis N, Tishler R, Tan M, Fasciano J, Sammartino DE, Posner MR. Induction chemotherapy with cisplatin and fluorouracil alone or in combination with docetaxel in locally advanced squamous-cell cancer of the head and neck: long-term results of the TAX 324 randomised phase 3 trial. Lancet Oncol. 2011; 12(2):153-9.

34. Pointreau Y, Garaud P, Chapet S, Sire C, Tuchais C, Tortochaux J, Faivre S, Guerrif S, Alfonsi M, Calais G. Randomized trial of induction chemotherapy with cisplatin and 5-fluorouracil with or without docetaxel for larynx preservation. J Natl Cancer Inst. 2009;101(7):498-506.

35. Lee AW, Tung SY, Ngan RK, Chappell R, Chua DT, Lu TX, Siu L, Tan T, Chan LK, Ng WT, et al. Factors contributing to the efficacy of concurrent-adjuvant chemotherapy for locoregionally advanced nasopharyngeal carcinoma: combined analyses of NPC-9901 and NPC-9902 Trials. Eur J Cancer. 2011; 47(5):656-66.

36. Liu GY, Lv X, Wu YS, Mao MJ, Ye YF, Yu YH, Liang H, Yang J, Ke LR, Qiu WZ, et al. Effect of induction chemotherapy with cisplatin, fluorouracil, with or 
without taxane on locoregionally advanced nasopharyngeal carcinoma: a retrospective, propensity score-matched analysis. Cancer commun (Lond). 2018;38(1):21.

37. Chen J, Qi J, Yu B, Peng XH, Wang F, Tan JJ, Chen QQ, Peng XY, Zeng FF, Liu X. A retrospective study to compare five induction chemotherapy regimens prior to radiotherapy in the reduction of regional lymph node size in patients with nasopharyngeal carcinoma. Med Sci Monit. 2018;24: 2562-8.

\section{Publisher's Note}

Springer Nature remains neutral with regard to jurisdictional claims in published maps and institutional affiliations.

Ready to submit your research? Choose BMC and benefit from:

- fast, convenient online submission

- thorough peer review by experienced researchers in your field

- rapid publication on acceptance

- support for research data, including large and complex data types

- gold Open Access which fosters wider collaboration and increased citations

- maximum visibility for your research: over $100 \mathrm{M}$ website views per year

At $\mathrm{BMC}$, research is always in progress.

Learn more biomedcentral.com/submissions 